\title{
Bringing Theory to the Field
}

This book arose from the badgering of Loïc Wacquant, who insisted that it was time to collect these essays, new and old, and throw down the gauntlet to the Chicago School. While I'm grateful for all his encouragement, forcing me to rethink once again what I have been doing for forty years, I could not follow his proposal to inaugurate a Berkeley school of ethnography. I doubt there could ever be a such a school, since Berkeley's distinction lies in the diversity of its approaches to everything, and to ethnography in particular. Our ethnographies run the gamut from Marxism to feminism and postcolonialism, from positivism to reflexive sociology, from symbolic interaction to comparative history. As ethnographers all we have in common is a commitment to studying others in their space and time. From the beginning the ethos of Berkeley sociology has always been antischool.

To deny the existence of a Berkeley school is not to say that my vision of ethnography appeared as an immaculate conception or was cultivated in heroic ethnographic isolation. To the contrary, 
the essays that follow have been forged in Berkeley since the midI980s: in debates with my colleagues, in courses on participant observation and methodology, in dissertation seminars that have generated a stream of ethnographically based books. Before Berkeley I learned my trade from Jaap van Velsen in the Zambian tributary of the Manchester School of social anthropology, and beyond Berkeley I absorbed much from my collaborations with János Lukács in Hungary, and Pavel Krotov and Tatyana Lytkina in Russia. Inevitably, my most supportive critic has been Erik Wright, an outsider to the cult of ethnography, always quick to point out nonsense in my writing - although sometimes nonsense has virtues that he won't acknowledge.

There is a second reason why my writings cannot be tied to a Berkeley school. Not only is there a rich diversity of traditions within Berkeley but the approach adopted here-the extended case method - is found in other departments around the world, and in other disciplines, most notably anthropology and geography. Within sociology, insisting on an ethnography that forges micro-macro connections through the reconstruction of social theory is not as heretical as it once was. Yet it does continue to face resistance from a naive empiricism that regards ethnography as special because it gets at the world as it "really is," that assumes social theory grows tabula rasa out of that reality, and therefore only by ridding ourselves of biases and prejudices can we coax the field into disclosing its truth. This naive empiricism is often combined with an equally naive positivism: to grasp reality we can and must stand outside the world we study. This presumes a social world divided into two spheres: one sphere occupied by the producers of objective knowledge, separated from a second sphere inhabited by the subjects of knowledge. 
In this view ethnographers must not disturb the worlds they study, but instead they must aspire to be the proverbial fly on the wall.

The approach of this book is very different. It is based on the following six postulates.

- We cannot see social reality without theory, just as we cannot see the physical world without our eyes. Everyone carries and uses social theory, cognitive maps of the world we inhabit, although not everyone is a social theorist, that is, someone who specializes in the production of such maps. Thus social theory ranges all the way from practical to tacit knowledge (knowledge we take for granted in conducting our lives) to abstract formalisms that look more like mathematical theorems than maps of the world.

- No impenetrable wall separates the worlds we study from our laboratories of science. To the contrary, we are inherently part of the world we study. What differentiates social scientists from the people they study is the theory they carry that allows them to see the world differently and, I would say, more deeply. I call the theory that we self-consciously develop analytical theory or social science, whereas the people we study possess an unreflective, usually tacit, theory that I call folk theory or common sense. Social scientists are not suspended in an ether of analytical theory; they too have their own folk theory. When it comes to their own lives, even their lives as sociologists, they all too easily suspend the insights they apply to others. Sad to say, we can be as unreflective and myopic about our everyday worlds as anyone else.

- Analytical theory or science reveals the broader context of our actions, but it also shows how the context creates the illusion 
of its own absence, of an everyday world that is autonomous and self-contained. We may blame ourselves for unemployment, whereas its sources are markets and governments-external forces that not only produce unemployment but also mystify that production. In revealing the connections between micro and macro we are developing what $\mathrm{C}$. Wright Mills called the sociological imagination. That is our vocation.

- The university is not a neutral terrain but a field of competing theoretical perspectives and methodological approaches, research programs, if you will, that offer different insights into the way micro and macro are connected. These divergent approaches form nodal points in a hierarchical field of power, refracting the impact of forces beyond its boundaries.

- Analytical theory enables us to see and thus comprehend the world, but that does not imply automatic confirmation. To the contrary, the world has an obduracy of its own, continually challenging the causal claims and predictions we make as social scientists on the basis of our theories. That is how we develop science, not by being right but by being wrong and obsessing about it.

- Analytical theory is not necessarily incomprehensible to lay people. Social science and common sense are not insulated and incommensurable. In other words, it is possible, but not always easy, to forge a passage from common sense to social science, and it is possible that one can elaborate a good sense within the common sense. Indeed, that is the task of the public ethnographer.

These postulates have their roots in four decades of participant observation, in the factories and mines of four countries 
(Zambia, the United States, Hungary, and Russia), resulting in studies of the microprocesses of four great transformations (decolonization, the transition to organized capitalism, the Soviet transition to socialism, and the transition from socialism to capitalism). You may well ask how a single ethnographer, working in a single factory, can illuminate a great transformation. Although definitive of the sociological imagination, the task may seem absurd to many a conventional ethnographer.

The answer lies with the extended case method, defined by its four extensions: the extension of observer into the lives of participants under study, the extension of observations over time and space; the extension from microprocesses to macroforces; and, finally and most important, the extension of theory. Each extension involves a dialogue: between participant and observer, between successive events in the field, between micro and macro, and between successive reconstructions of theory. These dialogues orbit around each other, each in the gravitational field of the others. To make sense of these dialogues the different studies described in this book make different simplifying assumptions.

In the first chapter I describe the genesis of the extended case method. In effect I apply the extended case method to my own participation in the academy and in the field-participations that are in dialogue with each other. In the second chapter I develop a more formal framework for the extended case method by reference to my study of race and class in postcolonial Zambia (1968-72). I end by developing two models of science: positive and reflexive, each autonomous but necessary for the other. The third chapter develops the idea of a reflexive science through the idea of the revisit. If my Zambia study was based on an extension 
back into history, an archeological dig, here I dwell on revisits to earlier ethnographies of the same place. The chapter sets out from a comparison of my own ethnography of a Chicago factory with one of the same factory conducted thirty years earlier. From there I examine other types of focused revisits but end by elevating the "revisit" as a trope for all ethnography.

The fourth chapter extends the ethnographic approach to comparative history, and it also extends the number of cases from two to three. It contrasts the analyses of revolutions found in the writings of Trotsky and Skocpol. It underlines the difference between the reflexive science of a participant observer and the positivist science of the comparative sociologist. In participating in the revolution that he studies, and in reconstructing the Marxist theory of socialist transition, Trotsky offers one prototype of the extended case method. The fifth chapter extends beyond three cases. It turns to the transition "back" from socialism to capitalism. It analyzes a series of successive factory, and then community, ethnographies that I carried out in Hungary and Russia between 1982 and 2002. It shows how each study built on preceding ones, wrestling first with a comparison of Hungary's state socialism and the organized capitalism of the United States and then with the Soviet transition from state socialism to market capitalism.

If the opening chapter is a self-analysis of my own trajectory, the concluding chapter focuses on my intellectual engagement with the four great transformations of the twentieth century. Here I try to assess the strengths and weaknesses of the extended case method, steering a course between romanticization of my subjects and reification of the external world. I ask what light my ethnographies have shed on these great transformations, 
what the latter have in common, how they are connected to each other, and what the implications are for the twenty-first century.

I have been accused of creating disasters wherever I go. After I left Zambia, the price of copper plummeted and Zambian society with it. After I left Allied Corporation, it went bankrupt along with the rest of south Chicago's industry. The area became an industrial wasteland. After I left Hungary, the Lenin Steel Works, and Hungarian industry more generally, disintegrated in the face of market forces, quickly catching up with south Chicago. I was in Russia for only seven months before the edifice of the Soviet Union crashed down on the heads of its workers. I plead innocent. I was not to blame. Correlation is not causality. All these sites became victim of what I call third-wave marketization, which began in the middle I970s, a tsunami that continues to devastate our planet. Ethnography offers an especially potent insight into the catastrophic collapse of so many communities, while extending the extended case method to global ethnography helps us discern common patterns around the world and the forces that create them.

I may not have been the cause of disaster capitalism, but that is not to say my ethnography was not without its effects. Indeed, one might think that ethnography's direct engagement with participants lends itself to public engagement. But this is far from necessarily being the case. While Trotsky's analysis definitely fits the category of public ethnography and so did my study of Zambianization, this was not true of the Chicago factory study or the studies in Hungary and Russia, which were more clearly aimed at an academic audience. Even these intently professional studies, however, by linking microprocesses to macroforces, provide the foundation for a public sociology that 
turns private problems into public issues. Ethnography may not necessarily be public sociology, but by engaging with suffering and domination, hierarchy and inequality, ethnography calls attention to our accountability to a world beyond and thereby inevitably raises the specter of public sociology. This is the topic of my epilogue.

Inevitably, the ethnographer's debts are enormous since our work is inherently collaborative. To recognize the anonymous actors of our field in a ritualistic sentence or two is an inadequate acknowledgment of our responsibilities to publics, both the ones upon whom we depend in the process of research and the ones to which we are more distantly connected. As for my academic colleagues, I have acknowledged their contributions to the individual essays at the end of each chapter. I am grateful to Harvey Molotch, Mitch Duneier, and Diane Wolf for their support for this project as a whole and to Art Stinchcombe and Diane Vaughan for their comments on the chapters that are new to this book. Most important, Naomi Schneider has been a font of support for ethnography, mine and others, since she arrived at the University of California Press twenty-five years ago. She has been a potent force behind the continuing ascendancy of the extended case method. 